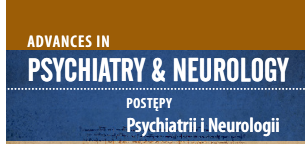

Correspondence to/

Adres do korespondencji:

Izabela Socha

Instytut Psychologii

Uniwersytet Łódzki

ul. Smugowa 10/12

91-433 Łódź

e-mail: izabela.socha@op.pl

Submitted/Otrzymano: 13.07.2017

Accepted/Przyjęto do druku: 28.09.2017

\section{SYMPTOMS OF POSTTRAUMATIC STRESS AMONG PARENTS STRUGGLING WITH THEIR CHILD'S CANCER - THE ROLE OF NEGATIVE COGNITIONS AND DISRUPTION IN CORE BELIEFS}

\section{OBJAWY STRESU POURAZOWEGO U RODZICÓW ZMAGAJĄCYCH SIĘ Z CHOROBA NOWOTWOROWA DZIECKA - ROLA NEGATYWNYCH TREŚCI POZNAWCZYCH I ZAKŁÓCEŃ W KLUCZOWYCH PRZEKONANIACH}

\author{
Nina Ogińska-Bulik', Izabela Socha ${ }^{1,2}$ \\ 'Institute of Psychology, University of Łódź, Łódź, Poland \\ 2"Krwinka" Foundation for Children Suffering from Cancer, Łódź, Poland \\ 'Instytut Psychologii, Uniwersytet Łódzki, Łódź, Polska \\ 2Fundacja dla Dzieci z Chorobami Nowotworowymi "Krwinka”, Łódź, Polska
}

\begin{abstract}
Purpose: The study aimed at establishing the relationship between posttraumatic cognitions resulting from traumatic experiences as well as disruption in core beliefs and the level of symptoms of posttraumatic stress (PTSD). Another aim was to check whether the disruption of core beliefs is a mediator between posttraumatic cognitions and symptoms of PTSD.

Methods: Results obtained from 57 parents aged 25-57 years $(M=35.38$; $S D=8.32$ ), who have dealt with their child's cancer (men - 47.4\%; women - 52.6\%) were examined. Three measuring methods were used in the study: the Impact of Event Scale-Revised (IES-R), Posttraumatic Cognitions Inventory (PTCI) and the Core Beliefs Inventory (CBI).

Results: The results showed positive associations between posttraumatic cognitions as well as disruption of core beliefs and the severity of PTSD. Challenges for core beliefs act as mediators in the relationship between posttraumatic cognitions and symptoms of PTSD.

Conclusions: The experience of a traumatic event usually entails the occurrence of posttraumatic stress symptoms. The severity of these symptoms is determined by, among others, the individual's beliefs about the world and about themselves. The experience of a child's cancer is a traumatic experience for parents. Negative cognitions and disruption in key beliefs favour the persistence of PTSD symptoms. Disturbances in beliefs are mediators in the relationship between negative cognitions and symptoms of PTSD. Reducing symptoms of PTSD, and thus recovery, requires a change in beliefs that are distorted by trauma.
\end{abstract}

Key words: posttraumatic stress symptoms, posttraumatic cognitions, disruption of core beliefs, child's cancer.

\title{
Streszczenie
}

Cel: Podjęte badania miały na celu ustalenie związku między pourazowymi treściami poznawczymi, wynikającymi z doświadczenia sytuacji traumatycznej i zakłóceniami w kluczowych przekonaniach, a poziomem objawów stresu potraumatycznego (posttraumatic stress disorder - PTSD) oraz sprawdzenie, czy zakłócenia w kluczowych przekonaniach pośredniczą w relacji między pourazowymi treściami poznawczymi a objawami PTSD. 
Symptoms of posttraumatic stress among parents struggling with their child's cancer - the role of negative cognitions and disruption in core beliefs Objawy stresu pourazowego u rodziców zmagających się z chorobą nowotworowa dziecka - rola negatywnych treści poznawczych i zakłóceń w kluczowych przekonaniach

Metody: Analizie poddano wyniki uzyskane od 57 rodziców w wieku 25-57 lat $(\mathrm{M}=35,38 ; \mathrm{SD}=8,32)$, którzy zmagali się z chorobą nowotworową dziecka. Mężczyźni stanowili 47,4\% badanych, a kobiety 52,6\%. W badaniach wykorzystano trzy narzędzia pomiaru, tj. Zrewidowaną Skalę Wpływu Zdarzeń, Inwentarz Pourazowych Treści Poznawczych oraz Inwentarz Podstawowych Przekonań Związanych z Negatywnym Zdarzeniem Życiowym.

Wyniki: Uzyskane wyniki wskazały na dodatnie związki pourazowych treści poznawczych i zakłóceń w kluczowych przekonaniach $\mathrm{z}$ nasileniem PTSD. Zakłócenia $\mathrm{w}$ kluczowych przekonaniach pełnią rolę mediatora $\mathrm{w}$ relacji między pourazowymi treściami poznawczymi a objawami PTSD.

Wnioski: Doświadczenie zdarzenia traumatycznego z reguły pociąga za sobą występowanie objawów stresu pourazowego. O nasileniu tych objawów decydują m.in. posiadane przez jednostkę przekonania dotyczące świata i własnej osoby. Doświadczenie choroby nowotworowej dziecka jest dla rodziców doświadczeniem traumatycznym. Negatywne treści poznawcze oraz zakłócenia w kluczowych przekonaniach sprzyjają utrzymywaniu się objawów PTSD. Zakłócenia w posiadanych przekonaniach pełnią rolę mediatora w relacji między negatywnymi treściami poznawczymi a objawami PTSD. Redukcja objawów PTSD, a tym samym powrót do zdrowia, wymaga zmiany przekonań zniekształconych w wyniku doznanej traumy.

Słowa kluczowe: objawy stresu pourazowego, pourazowe treści poznawcze, zakłócenia w kluczowych przekonaniach, choroba nowotworowa dziecka.

\section{PURPOSE}

\section{Cancer as traumatic experience}

Cancer belongs to a group of life-threatening diseases. This is why it is treated as a negative event in life or a traumatic event. A particularly painful situation is experiencing one's own child's cancer.

Parents of an ill child may experience trauma connected with the process of diagnosis, the seriousness of the disease and the level of threat to the child's life, the child feeling lonely, for instance in connection with his or her stay at the hospital, the duration of the disease, recurring surgeries or unfavourable outlook [1]. Many parents struggling with their child's cancer are found to show symptoms of depression and posttraumatic stress disorder (PTSD), which mainly comprises intrusions in the form of recurring images, dreams and trauma-related thoughts, arousal indicating increased alertness and fear, as well as avoidance shown by way of attempts to discard thoughts and emotions connected with the experienced event [2-4]. Research mentioned by Baran [5] indicates that $95 \%$ of mothers whose children got cancer showed the presence of symptoms of intrusion, half of them showed symptoms of arousal and $40 \%$ symptoms of avoidance. The percentage of parents showing a full form of posttraumatic stress disorder amounted to 6-11\%.

However, it should be emphasised that not all people who were exposed to a traumatic event show symptoms of PTSD, whereas in case of most people who have shown them, the symptoms are gradually subsiding over time. Still, there are people who continue to show the same level of such symptoms. This is why it seems to be justified to ask why does it happen and what determines the continuation of pathological elements?

\section{CEL}

\section{Choroba nowotworowa jako doświadczenie traumatyczne}

Choroba nowotworowa należy do grupy chorób zagrażających życiu człowieka. Z tego też względu jest traktowana jako negatywne zdarzenie życiowe lub zdarzenie o charakterze traumatycznym. Szczególnie dotkliwą sytuacją jest doświadczenie choroby nowotworowej własnego dziecka.

Rodzice chorych dzieci mogą doświadczać traumy związanej z procesem diagnozy, powagą choroby i stopniem zagrożenia dla życia, poczuciem osamotnienia dziecka związanym na przykład z pobytem w szpitalu, czasem trwania choroby, powtarzającymi się zabiegami czy niekorzystnymi rokowaniami [1]. U wielu rodziców zmagających się z chorobą nowotworową dziecka stwierdza się występowanie objawów depresji i stresu pourazowego (posttraumatic stress disorder - PTSD), na który składają się przede wszystkim intruzje, wyrażające powracające obrazy, sny i myśli związane $\mathrm{z}$ traumą, pobudzenie, wskazujące na wzmożoną czujność i występowanie lęku, oraz unikanie, przejawiające się próbami pozbycia się myśli i emocji związanych $z$ doświadczonym zdarzeniem [2-4]. Badania przytaczane przez Baran [5] wskazują, że 95\% matek, których dzieci zachorowały na raka, ujawniło występowanie objawów intruzji, połowa z nich objawy pobudzenia, a $40 \%$ unikania. Odsetek rodziców wykazujących pełny zespół stresu pourazowego wynosił 6-11\%.

Należy jednak podkreślić, że nie u wszystkich osób, które były narażone na zdarzenie traumatyczne, występują objawy PTSD, a u większości osób, u których się pojawiły, stopniowo, wraz z upływem czasu, zanikają. Jednakże są także osoby, u których tego typu objawy się utrzymują. Zasadne zatem wydaje się pytanie, dlaczego tak się dzieje, co decyduje o podtrzymywaniu elementów patologii. 


\section{Core beliefs and symptoms of posttraumatic stress disorder}

Experiencing a traumatic situation is a significant challenge for key (core) beliefs (assumptions, cognitive schemata) concerning the world and oneself, forcing most people who have experienced albo concerning the world and oneself and it forces most people who have experienced it to revise these beliefs. This is because trauma constitutes a factor which is an immense threat to integrity of one's assumptions regarding the world and oneself. Individual cognitive activity in the light of trauma is one of the most important factors affecting the outcome of experienced events, including symptoms of PTSD [6-8].

Whenever symptoms of PTSD persist, it shows the inefficiency of mechanisms for coping with experienced events, i.e. it is a result of an inability to cognitively process the trauma in appropriate way. On the other hand, when people who have experienced trauma recover, it is seen as a result of its positive processing. The process of cognitive processing of trauma refers to integration of information on the experienced event with already possessed, previously shaped cognitive schemata [9].

Foa and Rothbaum's [7] emotional processing theory treats the occurrence of PTSD as a consequence of cognitive disruption which has occurred. The authors distinguish two dysfunctional beliefs which are connected with the development of symptoms of PTSD. The first one construes the world as a dangerous place and the second one stipulates that people are unable to adequately handle negative events in life. The authors also emphasise that the more rigid and unchanging cognitive schemata of an individual, the more the individual will be vulnerable to symptoms of PTSD developing, regardless of whether these are negative or positive schemata.

The occurrence of symptoms of PTSD as a result of an unfavourable cognitive adaptation to changes resulting from adverse events in life is also noted by Janoff-Bulman in his Shattered Assumptions Theory [10, 11]. People confronted with such events usually undertake cognitive operations aimed at adjustment to reality, but their beliefs may also remain unchanged. This means that previously established cognitive schemata may be rejected as a result of experienced trauma or they can be confirmed and reinforced. The persistence of strong, rigid beliefs (both negative and positive) can accompany depression, fear, regret and other negative outcomes resulting from experienced trauma [12].

The significance of negative cognitive schemata with extreme severity for development and maintenance of symptoms of PTSD is also emphasised by Ehlers and Clark [13]. The authors stress that negative cognitive assessment of an experienced traumatic situation maintains individual's sense of being endangered, which is in turn connected with intrusions and strong

\section{Podstawowe przekonania a objawy stresu pourazowego}

Przeżycie sytuacji traumatycznej stanowi istotne wyzwanie dla kluczowych (podstawowych) przekonań (założeń, schematów poznawczych) dotyczących świata oraz własnej osoby i zmusza większość ludzi, którzy jej doświadczyli, do zrewidowania tych przekonań. Trauma stanowi bowiem czynnik silnie zagrażający integralności posiadanych założeń wobec świata i własnej osoby. Aktywność poznawcza jednostki podejmowana w obliczu tramy jest jednym $\mathrm{z}$ ważniejszych czynników wpływających na ponoszone skutki doświadczonych zdarzeń, w tym na objawy PTSD [6-8].

Utrzymywanie się objawów PTSD wskazuje na nieskuteczność mechanizmów radzenia sobie z doświadczonymi wydarzeniami, czyli jest wynikiem nieumiejętności adekwatnego poznawczego przetworzenia traumy. Z kolei powrót do zdrowia ludzi, którzy doświadczyli traumy, jest traktowany jako wynik skutecznego jej przetworzenia. Proces poznawczego przetwarzania traumy (cognitive processing) odnosi się do integrowania informacji o doświadczonym zdarzeniu z posiadanymi, ukształtowanymi wcześniej schematami poznawczymi [9].

Foa i Rothbaum [7] w swojej teorii emocjonalnego przetwarzania traumy traktują występowanie PTSD jako konsekwencję występujących zniekształceń poznawczych. Autorki wyróżniły dwa dysfunkcjonalne przekonania, które są związane z rozwojem objawów tego zespołu. Pierwsze oznacza, że świat jest miejscem niebezpiecznym, drugie wskazuje, że człowiek nie jest w stanie adekwatnie poradzić sobie z negatywnymi wydarzeniami życiowymi. Autorki podkreślają także, że im bardziej sztywne i niepodatne na zmiany schematy poznawcze będzie przejawiać jednostka, tym bardziej będzie narażona na rozwój objawów PTSD, i to niezależnie od tego, czy są to schematy negatywne czy pozytywne.

Na występowanie objawów PTSD w wyniku niekorzystnej adaptacji poznawczej do zmian wywołanych niepomyślnymi wydarzeniami życiowymi zwraca także uwagę Janoff-Bulman w swojej teorii rozbitych założeń $[10,11]$. Człowiek w konfrontacji z takimi wydarzeniami zwykle podejmuje operacje poznawcze, które służą dopasowaniu przekonań do rzeczywistości, ale może także utrzymywać te przekonania w niezmienionej postaci. Oznacza to, że wcześniej posiadane schematy poznawcze w wyniku doznanej traumy mogą ulec odrzuceniu, ale mogą także zostać potwierdzone i usztywnione. Utrzymywanie się silnych, sztywnych przekonań (zarówno negatywnych, jak i pozytywnych) współwystępuje z objawami depresji, lęku, żalu oraz innymi negatywnymi następstwami wynikającymi z doświadczonej traumy [12].

Znaczenie negatywnych schematów poznawczych o skrajnym nasileniu dla rozwoju i podtrzymywania objawów PTSD akcentują także Ehlers i Clark [13]. Autorzy podkreślają, że negatywna ocena poznawcza doświad- 
psycho-physiological arousal, as well as occurrence of negative emotions.

An interesting question may be one pertaining to the genesis of relationship between negative convictions about the world and oneself, and symptoms of PTSD. It seems that disruption of core beliefs may be used as a mechanism to clarify the relationship. Disruption of core beliefs means one's inclination to ponder over oneself and the world, own abilities, significance of one's life or future, having experienced trauma. This inclination to re-evaluation of one's beliefs may lead to their change, adjustment to a new reality which changed as a result of experienced trauma, or be a source of positive change reflected in the form of posttraumatic growth. The changes mainly concern perception of oneself, relationships with others and life philosophy [14].

The authors of the posttraumatic growth model [14] show that disruption of core beliefs, which is also referred to as a challenge to core beliefs, is the starting point for the trauma cognitive processing process. The objective of the process is to assign meaning and significance to the experienced event $[9,15]$.

At first, disruption to cognitive beliefs may intensify symptoms of PTSD; however, later they tend to alleviate them, and thus help restore one's health. Moreover, as Cann et al. [16] show, the tendency to revise beliefs may lead to occurrence of positive posttraumatic changes expressed in the form of posttraumatic growth.

\section{METHODS}

The undertaken research was aimed at determining the relationship between negative convictions concerning oneself and the surrounding world (referred to as negative cognitions) and disruption of core beliefs, and intensification of symptoms of PTSD among parents who experienced a traumatic event in the form of their child's cancer.

Answers to the following research questions have been sought for:

- To what degree examined parents who experienced their child's cancer show symptoms of PTSD?

- What is the level of negative cognitions and disruption of core beliefs among people in the analysed group?

- Are disruption of core beliefs and negative cognitions connected with symptoms of PTSD?

- Does disruption of core beliefs act as an intermediary in the relationship between negative cognitions and symptoms of PTSD?

On the basis of presented theories [7, 10, 13, 14], it was assumed that negative cognitions and disruption of core beliefs are going to be positively correlated with symptoms of PTSD. Moreover, it may be assumed that czonej sytuacji traumatycznej podtrzymuje u jednostki poczucie zagrożenia, które z kolei wiąże się z intruzjami i silnym pobudzeniem psychofizjologicznym, a także z występowaniem negatywnych emocji.

Interesujące wydaje się pytanie o to, co leży u podłoża związku między negatywnymi przekonaniami na temat świata i własnej osoby a objawami PTSD. Wydaje się, że mechanizmem, który może wyjaśniać tę relację, są zakłócenia w kluczowych przekonaniach (disruption of core beliefs). Zakłócenia w kluczowych przekonaniach oznaczają skłonność osoby, która doświadczyła traumy, do zastanawiania się nad sobą i światem, własnymi możliwościami, znaczeniem swojego życia czy przyszłością. Ta skłonność do ponownej oceny (reewaluacja) przekonań może prowadzić do ich zmiany, dopasowania się do nowej, zmienionej w wyniku doznanej traumy rzeczywistości, a także być źródłem pozytywnych zmian, odzwierciedlanych $\mathrm{w}$ postaci potraumatycznego wzrostu. Zmiany te dotyczą przede wszystkim percepcji siebie, relacji z innymi i filozofii życiowej [14].

Autorzy modelu potraumatycznego wzrostu [14] wskazują, że zakłócenia w kluczowych przekonaniach, określane także jako wyzwanie dla kluczowych przekonań (challenge to core beliefs), są punktem wyjścia procesu przetwarzania poznawczego traumy. Celem tego procesu jest nadanie doświadczonemu wydarzeniu sensu i znaczenia $[9,15]$.

Zakłócenia w posiadanych przekonaniach poznawczych mogą początkowo nasilać objawy PTSD, jednak w późniejszym okresie $\mathrm{z}$ reguły prowadzą do ich redukcji, a tym samym przywracania zdrowia. Ponadto, jak wskazują Cann i wsp. [16], skłonność do rewizji przekonań może prowadzić do wystąpienia pozytywnych zmian potraumatycznych wyrażanych w postaci potraumatycznego wzrostu.

\section{METODY}

Podjęte badania miały na celu ustalenie związku między negatywnymi przekonaniami dotyczącymi własnej osoby i otaczającego świata (określanymi jako negatywne treści poznawcze) i zakłóceniami w kluczowych przekonaniach a nasileniem objawów PTSD u rodziców, którzy doświadczyli zdarzenia traumatycznego, jakim była choroba nowotworowa dziecka.

Poszukiwano odpowiedzi na następujące pytania badawcze:

- W jakim stopniu badani rodzice, którzy doświadczyli choroby nowotworowej dziecka, ujawniają objawy stresu pourazowego?

- Jaki jest poziom negatywnych treści poznawczych oraz zakłóceń w kluczowych przekonaniach w badanej grupie?

- Czy negatywne treści poznawcze i zakłócenia w kluczowych przekonaniach wiążą się z objawami PTSD?

- Czy zakłócenia w kluczowych przekonaniach pośredniczą w relacji między negatywnymi treściami poznawczymi a objawami PTSD? 
negative cognitions will be positively correlated with disruption of core beliefs and that disruption of beliefs will act as an intermediary in the relationship between negative cognitions and symptoms of PTSD.

The analysis involved 60 parents whose children got cancer (leukaemia, tumours of the brain and the central nervous system, lymphomas and bone cancer). The analysis was conducted at Fundacja Pomocy Dzieciom z Chorobą Nowotworową in Warsaw and at hospices for ill children in Warsaw and in Białystok. The participants were informed about the objective of the research and their anonymity. An approval from the relevant Bioethics Committee for conducting the research was obtained. The analysis involved results obtained from 57 parents ( 3 people have not filled in all fields in questionnaires which were provided to them) aged 25-57 $(\mathrm{M}=35.38 ; \mathrm{SD}=8.32)$. There were $47.4 \%$ of men and $52.6 \%$ of women among the group of respondents.

The following methods were used in the study: the Impact of Event Scale (IES), Posttraumatic Cognitions Inventory (PTCI) and the Core Beliefs Inventory (CBI).

The Impact of Event Scale is a Polish adaptation of the Impact of Event Scale-Revised (IES-R) by Weiss and Marmar, adjusted to the Polish setting by Juczyński and Ogińska-Bulik [18]. The Scale is used to determine the subjective feeling of discomfort in connection with the event which has occurred. It contains 22 statements and measures the general index of intensity of PTSD and its three dimensions, i.e.: (1) intrusion in the form of recurring images, dreams, thoughts or perceptive impressions connected with trauma; (2) arousal characterised by hypervigilance, fear, irritability, difficulty focusing; and (3) avoidance in the form of trying to get rid of thoughts, emotions or conversations related to trauma. The respondent makes an assessment using the 5-point Likert scale. The tool is characterised by satisfactory psychometric parameters (the Cronbach's a coefficient for the entire scale is 0.92).

The Posttraumatic Cognitions Inventory (PTCI) by Foa et al. [19] was adapted to the Polish setting by Dragan, Gulcz and Wójtowicz [8]. The tool comprises 36 statements describing posttraumatic cognitions (e.g. "I can't trust that I will do the right thing"). The examined person expresses his or her position regarding these statements by selecting answers on a scale from "I completely agree" (1 point) to "I completely disagree" (7 points). The statements in the questionnaire are worded in a negative manner and they build up three scales: negative cognitions about self-scale, negative cognitions about world scale and self-blame scale. The higher the result of the respondent, the more the respondent agrees with these negative statements. The Cronbach's a internal consistency coefficient for the Polish version of the tool for
Odwołując się do zaprezentowanych teorii $[7,10,13$, 14] oraz dostępnych w tym zakresie badań, założono, że negatywne treści poznawcze oraz zakłócenia w kluczowych przekonaniach będą dodatnio powiązane $\mathrm{z}$ objawami PTSD. Ponadto można przypuszczać, że negatywne treści poznawcze będą dodatnio powiązane z zakłóceniami w kluczowych przekonaniach i że zakłócenia w przekonaniach będą pośredniczyć $\mathrm{w}$ relacji między negatywnymi treściami poznawczymi a objawami PTSD.

Badaniami objęto 60 rodziców, których dzieci zachorowały na raka (białaczka, nowotwory mózgu i ośrodkowego układu nerwowego, chłoniaki, nowotwory kości). Badania przeprowadzono w Fundacji Pomocy Dzieciom z Chorobą Nowotworową w Warszawie oraz w hospicjum dla dzieci chorych w Warszawie i Białymstoku. Uczestnikom wyjaśniono cel badań oraz poinformowano o ich anonimowości. Na przeprowadzenie badań uzyskano zgodę odpowiedniej Komisji Bioetyki. Analizie poddano wyniki badań uzyskane od 57 rodziców (trzy osoby niekompletnie wypełniły dostarczone im kwestionariusze) w wieku 25-57 lat $(\mathrm{M}=35,38 ; \mathrm{SD}=8,32)$. Mężczyźni stanowili $47,4 \%$ badanych, a kobiety $52,6 \%$.

W badaniach wykorzystano zrewidowaną Skalę Wpływu Zdarzeń, Inwentarz Pourazowych Treści Poznawczych oraz Inwentarz Podstawowych Przekonań Związanych z Negatywnym Zdarzeniem Życiowym.

Skala Wpływu Zdarzeń jest polską adaptacją zrewidowanej wersji Impact of Event Scale (IES-R) Weissa i Marmara [17], zaadaptowaną do warunków polskich przez Juczyńskiego i Ogińską-Bulik [18]. Służy do ustalenia subiektywnego poczucia dyskomfortu związanego z zaistniałym zdarzeniem. Zawiera 22 twierdzenia i mierzy ogólny wskaźnik nasilenia PTSD oraz jego trzy wymiary, tj.: 1) intruzję, wyrażającą powracające obrazy, sny, myśli lub wrażenia percepcyjne związane $z$ traumą, 2) pobudzenie, charakteryzujące się wzmożoną czujnością, lękiem, zniecierpliwieniem, trudnościami w koncentracji uwagi, oraz 3) unikanie, przejawiające się wysiłkami pozbycia się myśli, emocji lub rozmów związanych z traumą. Osoba badana dokonuje oceny, posługując się 5-stopniową skalą typu Likerta. Narzędzie charakteryzuje się satysfakcjonującymi parametrami psychometrycznymi (wskaźnik alfa Cronbacha dla całej skali wynosi 0,92).

Inwentarz Pourazowych Treści Poznawczych (Posttraumatic Cognitions Inventory - PTCI), którego autorami są Foa i wsp. [19], został zaadaptowany do warunków polskich przez Dragan, Gulcz i Wójtowicza [8]. Narzędzie składa się z 36 stwierdzeń opisujących pourazowe treści poznawcze (np. „Nie mam zaufania, że postąpię właściwie”). Badana osoba ustosunkowuje się do podanych stwierdzeń, wybierając odpowiedzi od zupetnie się nie zgadzam (1 punkt) do w petni się zgadzam (7 punktów). Twierdzenia $\mathrm{w}$ kwestionariuszu są sformułowane w sposób negatywny i tworzą trzy skale: skale negatywnych treści poznawczych dotyczacych własnej osoby, skale negatywnych treści po- 
Symptoms of posttraumatic stress among parents struggling with their child's cancer - the role of negative cognitions and disruption in core beliefs Objawy stresu pourazowego u rodziców zmagających się z chorobą nowołworowa dziecka - rola negatywnych treści poznawczych i zakłóceń w kluczowych przekonaniach

Table 1. The level of analysed variables

Tabela 1. Poziom analizowanych zmiennych

\begin{tabular}{|l|c|c|}
\hline Analysed variables/Analizowane zmienne & M & SD \\
\hline $\begin{array}{l}\text { PTSD - general/PTSD - ogółem } \\
\text { Intrusion/Intruzja }\end{array}$ & 50.23 & 17.72 \\
\hline Arousal/Pobudzenie & 20.68 & 6.71 \\
\hline Avoidance/Unikanie & 15.35 & 6.93 \\
\hline $\begin{array}{l}\text { Negative cognitions in general/ } \\
\text { Negatywne treści poznawcze - ogółem }\end{array}$ & 96.19 \\
\hline $\begin{array}{l}\text { Negative cognitions regarding oneself/Negatywne treści dotyczące własnej osoby } \\
\text { Negative cognitions regarding the world/Negatywne treści dotyczące świata }\end{array}$ & 27.71 \\
\hline Self-blame/Samoobwinianie & 8.10 & 10.75 \\
\hline Disruption to beliefs/Zakłócenia w posiadanych przekonaniach & 56.28 & 2.18 \\
\hline
\end{tabular}

M- mean/średnia, SD - standard deviation/odchylenie standardowe

general evaluation of the Posttraumatic Cognitions Inventory was 0.97 .

The Core Beliefs Inventory (CBI) by Cann et al. [16] comprises 9 statements concerning disruption of key (core) beliefs, which occurred as a result of experienced negative life events (e.g. "Because of the event, I seriously examined the degree to which I believe things that happen to people are fair"). The respondents assume a position regarding each statement in the questionnaire by using expressions, such as not at all (0 p.), to a very small degree (1 p.), to a small degree (2 p.), to a moderate degree (3 p.), to a great degree (4 p.), to a very great degree (5 p.). The more points, the higher the respondent's inclination to revise their previous beliefs. The analysis of psychometric properties of the tool brought satisfactory results. The Cronbach's a coefficient in several American evaluations ranged from 0.82 to 0.87 [16], and for the examined group of parents struggling with their child's cancer it amounted to $0.91^{1}$.

\section{RESULTS}

The spread of results of examined variables is normal; hence the calculation employed parametric tests, i.e. the Student's $t$-test for determination of differences between means as well as Pearson correlation coefficients (Pearson's $r$ ) to evaluate the relationship between variables. The analysis of mediation was performed using the bootstrapping method.

Table 1 contains means for obtained variables.

The obtained level of symptoms of PTSD is close to the level of these symptoms obtained during research aimed at determining psychometric properties of the Impact of Event Scale [18]. Considering criteria for that tool (33 points, as the border value), it was

\footnotetext{
${ }^{1}$ Currently, work on a Polish adaptation of the Core Beliefs Inventory is underway.
}

znawczych dotyczacych świata i skale samoobwiniania. Im wyższe wyniki uzyskuje osoba badana, tym w większym stopniu zgadza się ona $\mathrm{z}$ negatywnymi stwierdzeniami. Wskaźnik zgodności wewnętrznej alfa Cronbacha polskiej wersji narzędzia dla wyniku ogólnego Inwentarza Pourazowych Treści Poznawczych wyniósł 0,97.

Inwentarz Podstawowych Przekonań Związanych z Negatywnym Zdarzeniem Życiowym, którego autorami są Cann i wsp. [16], składa się z 9 stwierdzeń dotyczących zakłóceń w kluczowych (podstawowych) przekonaniach, jakie wystąpiły w wyniku doświadczonych negatywnych wydarzeń życiowych (np. „Z powodu tego zdarzenia poważnie zastanawiałem/am się, do jakiego stopnia to, co się przydarza ludziom, jest sprawiedliwe"). Osoba badana ustosunkowuje się do poszczególnych pozycji kwestionariusza, posługując się określeniami wcale (0 pkt), w bardzo malym stopniu (1 pkt), $w$ malym stopniu (2 pkt), w umiarkowanym stopniu (3 pkt), w dużym stopniu (4 pkt) i $w$ bardzo dużym stopniu (5 pkt). Im wyższa punktacja, tym większa skłonność badanego do rewizji dotychczasowych przekonań. Narzędzie uzyskało dobre właściwości psychometryczne. Wskaźnik alfa Cronbacha w kilku badaniach amerykańskich wahał się od 0,82 do 0,87 [16], a w badanej grupie rodziców zmagających się z chorobą nowotworową dziecka wyniósł $0,91^{1}$.

\section{WYNIKI}

Rozkłady wyników badanych zmiennych wyjaśnianych mają charakter normalny, dlatego do obliczeń wykorzystano testy parametryczne, tj. test $t$-Studenta do ustalenia różnic między średnimi i współczynniki korelacji $r$-Pearsona do oszacowania związku między zmiennymi. Analizę mediacji wykonano na podstawie metody bootstrappingu.

$\mathrm{W}$ tabeli 1 zamieszczono średnie uzyskanych zmiennych.

${ }^{1}$ Obecnie prowadzone są prace nad polską adaptacją The Core Beliefs Inventory. 
Table 2. Correlation coefficients between negative cognitive beliefs and disruption of core beliefs and symptoms of PTSD Tabela 2. Współczynniki korelacji między negatywnymi treściami poznawczymi i zakłóceniami w kluczowych przekonaniach a objawami PTSD

\begin{tabular}{|l|c|c|c|c|}
\hline $\begin{array}{l}\text { Analysed variables/ } \\
\text { Analizowane zmienne }\end{array}$ & $\begin{array}{c}\text { PTSD - general/ } \\
\text { Ogółem }\end{array}$ & $\begin{array}{c}\text { Intrusion/ } \\
\text { Intruzja }\end{array}$ & $\begin{array}{c}\text { Arousal/ } \\
\text { Pobudzenie }\end{array}$ & $\begin{array}{c}\text { Avoidance/ } \\
\text { Unikanie }\end{array}$ \\
\hline $\begin{array}{l}\text { Negative cognitions in general/ } \\
\text { Negatywne treści poznawcze - ogółem }\end{array}$ & $0.37^{* *}$ & $0.39^{* *}$ & $0.38^{* *}$ & 0.23 \\
$\begin{array}{l}\text { Negative cognitions regarding oneself/ } \\
\text { Negatywne treści dotyczące własnej osoby }\end{array}$ & 0.23 & $0.28^{*}$ & 0.22 & 0.12 \\
\hline $\begin{array}{l}\text { Negative cognitions regarding the world/ } \\
\text { Negatywne treści dotyczące świata }\end{array}$ & 0.18 & 0.18 & 0.19 & 0.11 \\
\hline Self-blame/Samoobwinianie & $0.39^{* *}$ & $0.41^{* *}$ & $0.40^{* *}$ & 0.25 \\
\hline Disruption of beliefs/Zakłócenia w przekonaniach & $0.51^{* * *}$ & $0.52^{* * *}$ & $0.43^{* *}$ & $0.43^{* *}$ \\
\hline
\end{tabular}

${ }^{* * *} p<0.001,{ }^{* *} p<0.01,{ }^{*} p<0.05$

Table 3. Correlation coefficients between negative cognitive beliefs and disruption of core beliefs Tabela 3. Współczynniki korelacji między negatywnymi treściami poznawczymi a zakłóceniami w kluczowych przekonaniach

\begin{tabular}{|l|c|}
\hline $\begin{array}{l}\text { Negative cognitions/ } \\
\text { Negatywne treści poznawcze: }\end{array}$ & $\begin{array}{c}|c| \\
\text { Disruption of beliefs/ } \\
\text { Zakłócenia w przekonaniach }\end{array}$ \\
\hline General/Ogółem & $0.42^{* *}$ \\
\hline Negative cognitions regarding oneself/Negatywne treści dotyczące własnej osoby & $0.27^{*}$ \\
\hline Negative cognitions regarding the world/Negatywne treści dotyczące świata & $0.42^{* *}$ \\
\hline Self-blame/Samoobwinianie & $0.41^{* *}$ \\
\hline
\end{tabular}

determined that 46 parents, i.e. $80.7 \%$ of respondents, show at least a moderate level and as few as 11 parents $(19.3 \%)$ are characterised by a low level of that variable.

There was also an analysis of factors comprising PTSD to see which of them are affected by the greatest changes. Due to the diversified number of items in individual subscales, the value of variables was divided by an appropriate number of statements; verification was performed to see if there are any statistically significant differences. The examined parents have shown a significantly higher level $(p<0.01)$ of intrusion $(\mathrm{M}=2.58$; $\mathrm{SD}=0.84)$ as compared to arousal $(\mathrm{M}=2.19 ; \mathrm{SD}=0.99)$ and avoidance $(\mathrm{M}=2.02 ; \mathrm{SD}=0.86)$.

The research also involved controlling socio-demographic variables, such as sex and age of parents of ill children and the time which has passed from the moment of diagnosis of their child's cancer. The sex does not differentiate the intensity of PTSD (men: $\mathrm{M}=51.67$; $\mathrm{SD}=17.97$; women: $\mathrm{M}=48.93$; $\mathrm{SD}=17.69 ; t=0.57$ ) nor any of its factors. Similarly, the age of examined parents is not connected with an intensification of these symptoms $(r=-0.15)$. Almost half of parents participating in the analysis (49.1\%) have experienced their child's illness within 5 years before the analysis, while remaining ones (50.9\%) have experienced it earlier, i.e. more than 5 years ago. The time which has passed from the experienced event does not differen-
Uzyskany poziom objawów PTSD jest zbliżony do poziomu tych symptomów uzyskanych w badaniach mających na celu ustalenie właściwości psychometrycznych Skali Wpływu Zdarzeń [18]. Uwzględniając kryteria dla tego narzędzia (33 punkty jako wartość graniczna), ustalono, że 46 rodziców, co stanowi 80,7\% badanych, ujawnia co najmniej umiarkowany, a zaledwie 11 rodziców (19,3\% badanych) niski poziom tej zmiennej.

Sprawdzono również, w którym z czynników składających się na PTSD występują największe zmiany. Ze względu na zróżnicowaną liczbę pozycji w poszczególnych podskalach wartości czynników podzielono przez przypadającą na nie liczbę stwierdzeń i sprawdzono, czy występują różnice istotne statystycznie. Badani rodzice ujawnili istotnie wyższy poziom $(p<0,01)$ intruzji $(\mathrm{M}=2,58 ; \mathrm{SD}=0,84) \mathrm{w}$ stosunku do pobudzenia $(\mathrm{M}=2,19$; $\mathrm{SD}=0,99)$ i unikania $(\mathrm{M}=2,02 ; \mathrm{SD}=0,86)$.

$\mathrm{W}$ badaniach kontrolowano także zmienne socjodemograficzne, tj. płeć, wiek rodziców chorych dzieci oraz czas, jaki upłynął od diagnozy choroby dziecka. Płeć nie różnicuje nasilenia PTSD (mężczyźni: $\mathrm{M}=51,67$; $\mathrm{SD}=17,97$; kobiety: $\mathrm{M}=48,93 ; \mathrm{SD}=17,69 ; t=0,57$ ) ani żadnego z jego czynników. Podobnie wiek badanych rodziców nie wiąże się $\mathrm{z}$ nasileniem tych symptomów $(r=-0,15)$. Połowa uczestniczących w badaniu rodziców $(49,1 \%)$ doświadczyła choroby dziecka w okresie do 5 lat przed przeprowadzonym badaniem, a pozostali (50,9\%) 
tiate the intensity of symptoms of PTSD (1. M = 49.29; $\mathrm{SD}=19.67 ; 2 . \mathrm{M}=51.14 ; \mathrm{SD}=15.91 ; t=-0.39)$.

The general result of posttraumatic cognitions is slightly lower than in case of psychiatric patients $(M=152.9$; $\mathrm{SD}=61.3)$ and slightly higher than in the group of students $(M=79.4$; $S D=41.0)$ participating in research concerning a Polish adaptation of Posttraumatic Cognitions Inventory.

The result obtained through the Core Beliefs Inventory after calculation (i.e. division of the average result by the number of statements included in the CBI) amounts to $3.08(\mathrm{SD}=1.12)$ and shows an average level of disruption of core beliefs. It is an approximate result to results obtained during American research $(M=3.02$; $\mathrm{SD}=1.06)$. The next step of data analysis involved verifying whether negative cognitions and disruption of core beliefs are connected with an intensification of PTSD. The resulting correlation coefficients are presented in Table 2.

As it is shown through correlation coefficients included in Table 2, negative cognitions has a positive correlation with symptoms of PTSD, mainly with intrusion and arousal. Disruption of core beliefs has a positive correlation with all symptoms of PTSD. This can be compared to American research [16] which showed slightly lower correlation coefficient values between disruption of beliefs and symptoms of PTSD measured using the same tools (for intrusion: $r=0.46$, arousal: $r=0.40$ and avoidance: $r=0.39$; $p<0.001)$.

The subsequent Table 3 presents correlation coefficients between negative cognitions and disruption of core beliefs.

Negative cognitions referring to all three areas have a positive correlation with disruption of core beliefs. Higher correlation coefficient values refer to negative cognitions concerning the world and self-blame, rather than negative cognitions concerning oneself.

The subsequent step for data analysis involved checking whether disruption of beliefs act as an intermediary or a mediator, or a suppressor with regard to relationship between negative cognitions and symptoms of PTSD. Mediation analysis was used for that purpose. It was conducted using the bootstrapping method proposed by Preacher and Hayes [20], described by Cichocka and Bilewicz [21]. The method enables determination of a more complex structure of a model for which the independent variable serving as a predictor (negative cognitions in the case at hand) is bound with the dependent variable (symptoms of PTSD) using a third variable serving as a mediator (disruption of beliefs). The intermediation effect occurs solely when the intermediate variable lowers the predictor value of the independent variable to the dependent variable. w okresie bardziej odległym, tj. więcej niż 5 lat temu. Czas od doświadczonej sytuacji nie różnicuje nasilenia objawów PTSD (1. $\mathrm{M}=49,29 ; \mathrm{SD}=19,67 ; 2 . \mathrm{M}=51,14$; $\mathrm{SD}=15,91 ; t=-0,39)$.

Ogólny wynik pourazowych treści poznawczych jest nieco niższy niż w grupie pacjentów psychiatrycznych $(\mathrm{M}=152,9 ; \mathrm{SD}=61,3)$ oraz nieco wyższy niż $\mathrm{w}$ grupie studentów $(\mathrm{M}=79,4 ; \mathrm{SD}=41,0)$ uczestniczących $\mathrm{w}$ badaniach dotyczących polskiej adaptacji Inwentarza Pourazowych Treści Poznawczych.

Wynik uzyskany w Inwentarzu Podstawowych Przekonań Związanych z Negatywnym Zdarzeniem Życiowym po przeliczeniu (tj. podzieleniu uzyskanej średniej przez liczbę stwierdzeń wchodzących w skład inwentarza) wynosi 3,08 $(\mathrm{SD}=1,12)$ i wskazuje na średni poziom zakłóceń w kluczowych przekonaniach. Jest to wynik zbliżony do rezultatów uzyskanych w badaniach amerykańskich $(\mathrm{M}=3,02 ; \mathrm{SD}=1,06)$. W kolejnym kroku analizy danych sprawdzono, czy negatywne treści poznawcze oraz zakłócenia w kluczowych przekonaniach są powiązane $\mathrm{z}$ nasileniem PTSD. Uzyskane współczynniki korelacji prezentuje tabela 2 .

Jak wskazują zamieszczone w tabeli 2 współczynniki korelacji, negatywne treści poznawcze wiążą się dodatnio z objawami PTSD, a przede wszystkim $\mathrm{z}$ intruzją i pobudzeniem. Zakłócenia w kluczowych przekonaniach dodatnio korelują ze wszystkim objawami PTSD. Dla porównania w badaniach amerykańskich [16] uzyskano nieco niższe wartości współczynników korelacji między zakłóceniami w przekonaniach a objawami PTSD mierzonych tymi samymi narzędziami (dla intruzji: $r=0,46$, pobudzenia: $r=0,40$, unikania: $r=0,39 ; p<0,001)$.

W tabeli 3 przedstawiono współczynniki korelacji między negatywnymi treściami poznawczymi a zakłóceniami w kluczowych przekonaniach.

Negatywne treści poznawcze odnoszące się do wszystkich trzech obszarów korelują dodatnio z zakłóceniami w posiadanych przekonaniach. Wyższe wartości współczynników korelacji odnoszą się do negatywnych treści poznawczych dotyczących świata i samoobwiniania niż negatywnych treści dotyczących własnej osoby.

W kolejnym kroku analizy danych sprawdzono, czy zakłócenia w posiadanych przekonaniach pośredniczą, czyli pełnią rolę mediatora lub supresora, w relacji między negatywnymi treściami poznawczymi a objawami PTSD. W tym celu wykorzystano analizę mediacji. Przeprowadzono ją na podstawie procedury bootstrappingu, zaproponowanej przez Preachera i Hayesa [20], opisanej przez Cichocką i Bilewicza [21]. Metoda ta pozwala na ustalenie bardziej złożonej struktury modelu, w którym zmienna niezależna, pełniąca funkcję predyktora (w tym przypadku negatywne treści poznawcze), wiąże się ze zmienną zależną (objawy PTSD) za pośrednictwem trzeciej zmiennej, pełniącej funkcję mediatora (zakłócenia 


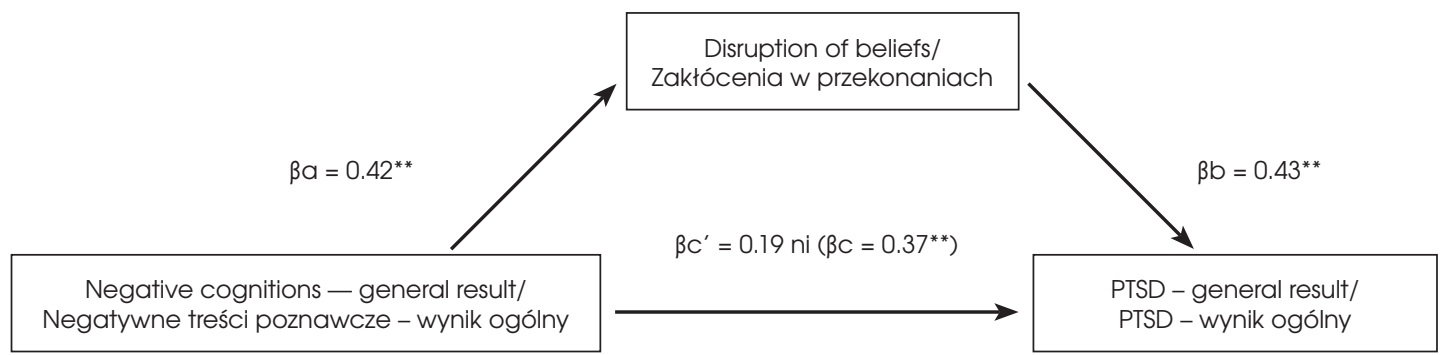

Figure I. The model for intermediation of disruption of beliefs in the relationship between negative cognitions and symptoms of PTSD (the general result)

Rycina I. Model mediacyjnej roli zakłóceń w przekonaniach w relacji pomiędzy negatywnymi treściami poznawczymi a objawami PTSD (wynik ogólny)

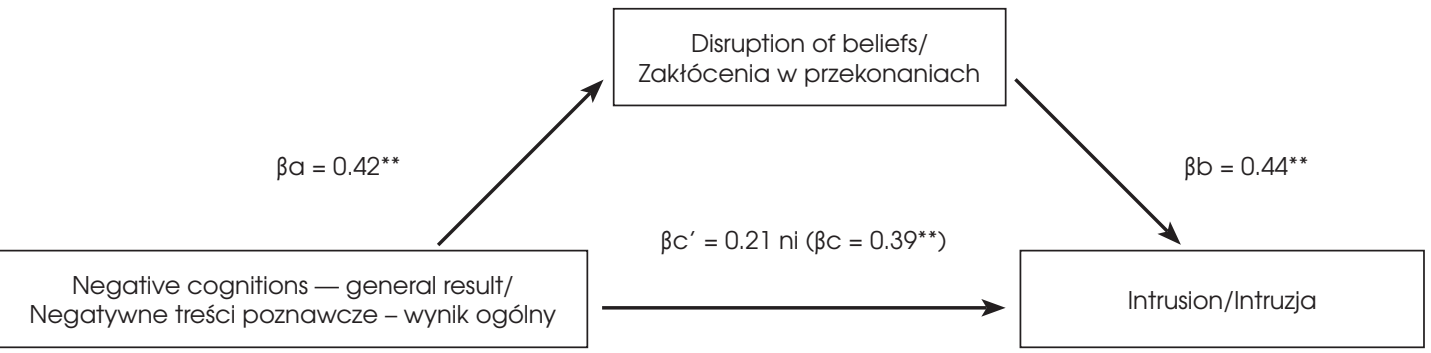

Figure II. The model for intermediation of disruption of beliefs in the relationship between negative cognitions and intrusion

Rycina II. Model mediacyjnej roli zakłóceń w przekonaniach w relacji pomiędzy negatywnymi treściami poznawczymi a intruzja

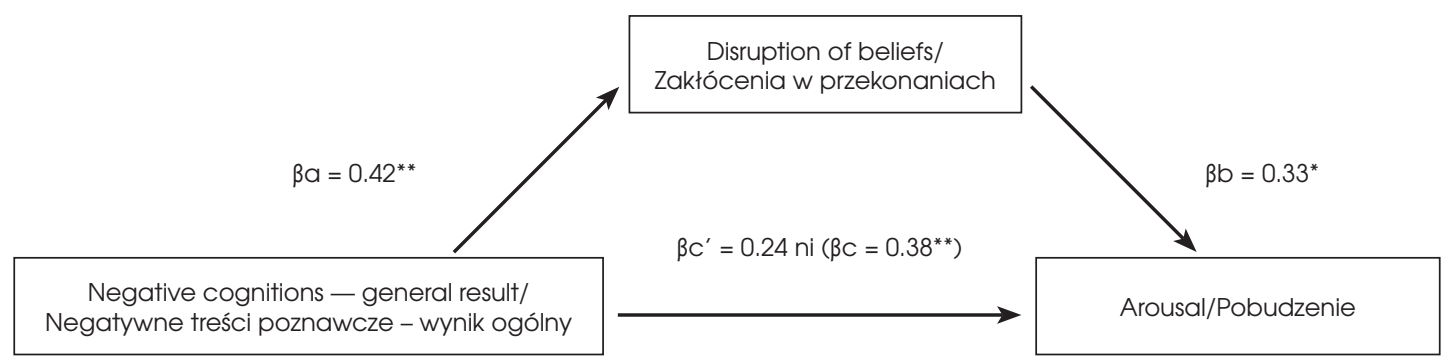

Figure III. The model for intermediation of disruption of beliefs in the relationship between negative cognitions and arousal

Rycina III. Model mediacyjnej roli zakłóceń w przekonaniach w relacji pomiędzy negatywnymi treściami poznawczymi a pobudzeniem

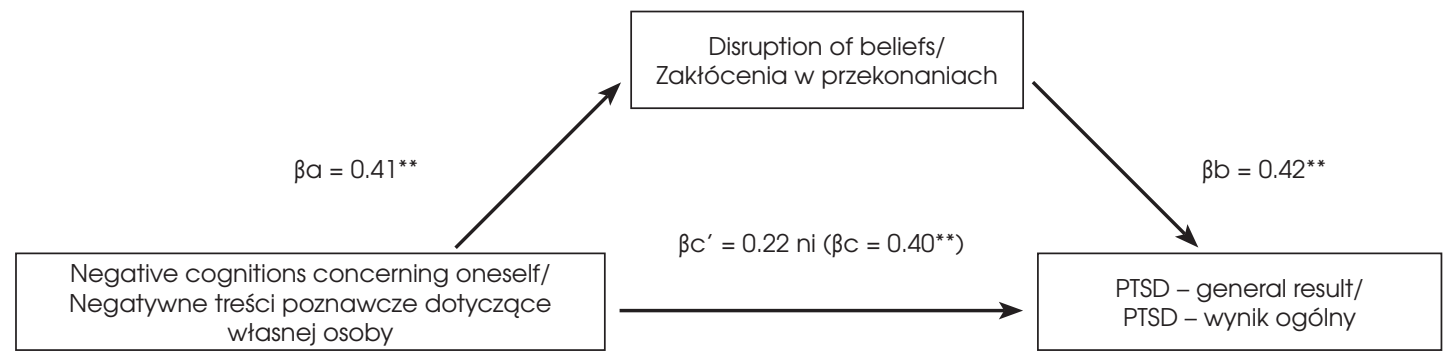

Figure IV. The model for intermediation of disruption of beliefs in the relationship between negative cognitions concerning oneself and symptoms of PTSD

Rycina IV. Model mediacyjnej roli zakłóceń w przekonaniach w relacji pomiędzy negatywnymi treściami poznawczymi dotyczącymi własnej osoby a objawami PTSD 
Symptoms of posttraumatic stress among parents struggling with their child's cancer - the role of negative cognitions and disruption in core beliefs Objawy stresu pourazowego u rodziców zmagających się z chorobą nowołworowa dziecka - rola negatywnych treści poznawczych i zakłóceń w kluczowych przekonaniach

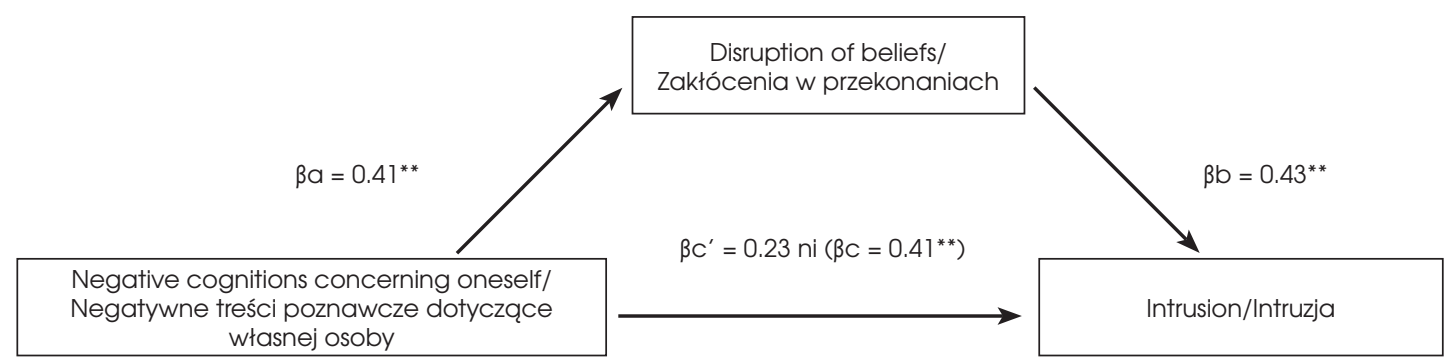

Figure V. The model for intermediation of disruption of beliefs in the relationship between negative cognitions concerning oneself and intrusion

Rycina V. Model mediacyjnej roli zakłóceń w przekonaniach w relacji pomiędzy negatywnymi treściami poznawczymi dotyczącymi własnej osoby a intruzją

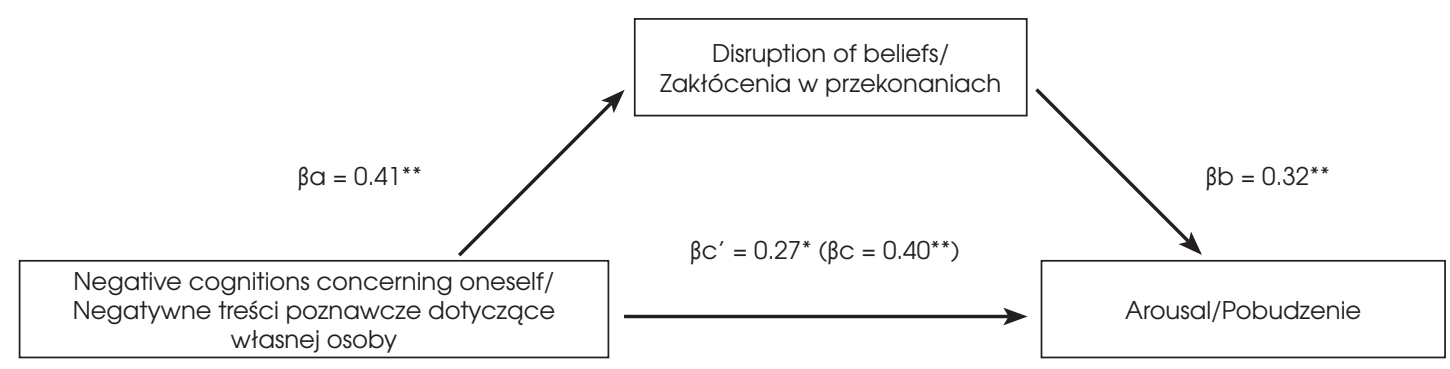

Figure VI. The model for intermediation of disruption of beliefs in the relationship between negative cognitions concerning oneself and arousal

Rycina VI. Model mediacyjnej roli zakłóceń w przekonaniach w relacji pomiędzy negatywnymi treściami poznawczymi dotyczącymi własnej osoby a pobudzeniem

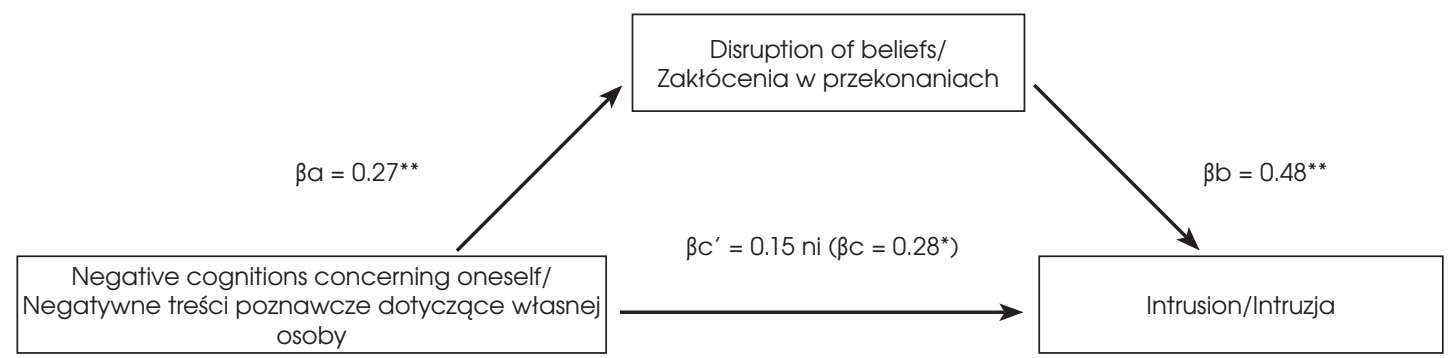

Figure VII. The model for intermediation of disruption of beliefs in the relationship between negative cognitions concerning the world and intrusion

Rycina VII. Model mediacyjnej roli zakłóceń w przekonaniach w relacji pomiędzy negatywnymi treściami poznawczymi dotyczącymi świata a intruzją

In case these values increase, the relationship is called suppression.

The dependent variable was assumed as the general result of the Impact of Event Scale and its individual factors. A confidence interval of $95 \%$ was established. A confidence interval in which there is a 0 shows that a particular intermediation is statistically significant. In general, 7 models were obtained, showing the intermediary nature of disruption of core beliefs in relation to negative cognitions and symptoms of PTSD. They are presented in Figures I-VII, on which $\beta c$ signifies w posiadanych przekonaniach). Efekt mediujący zachodzi wtedy, gdy zmienna pośrednicząca obniża własności predykcyjne zmiennej niezależnej na zmienną zależną. Natomiast w sytuacji podwyższenia tych własności mówimy o supresji.

Za zmienną zależną przyjęto zarówno ogólny wynik Skali Wpływu Zdarzeń, jak i jej poszczególne czynniki. Założono przedział ufności równy 95\%. Przedział ufności, w którym nie występuje 0 , wskazuje, że dana mediacja jest istotna statystycznie. Ogółem uzyskano 7 modeli wskazujących na mediującą rolę zakłóceń w kluczowych 
predictive values of the independent variable before the introduction of the mediator, whereas $\beta c^{\prime}$ signifies the value of the independent variable after the introduction of the mediator.

As can be seen in Figure I, the initial relationship between the independent (explanatory) variable and the dependent (explained) variable subsides after the introduction of the third variable in the form of a mediator, which indicates full intermediation. Negative cognitions has a positive correlation with disruption of core beliefs, which, in turn, has a positive correlation with symptoms of PTSD. This shows that the higher the intensity of negative cognitions shown by a person who has experienced trauma and the higher their inclination to make a review of their beliefs, the higher is their level of symptoms of PTSD. Similar dependencies occur when the dependent variable takes the form of symptoms of PTSD: intrusion (Figure II) and arousal (Figure III).

More detailed analyses considering individual areas of negative cognitions as an independent variable show the significance of negative convictions concerning oneself for disruption of core beliefs and persistence of PTSD symptoms, i.e. the general result, as well as intrusion and agitation (Figures IV-VI).

All aforementioned cases concern full mediation because the introduction of the mediator causes the dependence between the independent and the dependent variable to fade. The higher the level of negative cognitions concerning oneself, the higher the propensity to revise one's beliefs and the higher the intensity of symptoms of PTSD, intrusion and arousal in particular.

The conducted analysis of mediation has also showed the significance of negative cognitions concerning the world to disposition to revise one's beliefs and persistence of symptoms of PTSD in the form of intrusion (Figure VII).

\section{DISCUSSION}

Child's cancer is connected with an elevated level of stress. This is proved by obtained results which indicate that as much as $80 \%$ of parents showed a moderate or a high level of PTSD, whereas only $20 \%$ showed a low level of PTSD. Slightly higher results concerned intrusion in relation to arousal and avoidance. The sex and age of parents, and the time which has passed since their child was diagnosed did not differentiate the intensity of symptoms of PTSD among the analysed group of parents.

Lack of norms for results used during the analysis of measuring tools, i.e. the Posttraumatic Cognitions Inventory and the Core Beliefs Inventory does not enable a determination of the level of negative cognitions and disruption of beliefs among the analysed group of parents przekonaniach $\mathrm{w}$ relacji między negatywnymi treściami poznawczymi a objawami PTSD. Przedstawiono je na rycinach I-VII, na których $\beta c$ oznacza wartości predykcyjne zmiennej niezależnej przed wprowadzeniem mediatora, a $\beta c^{\prime}$ - wartość zmiennej niezależnej po wprowadzeniu mediatora.

Jak widać na rycinie I początkowy związek między zmienną niezależną (wyjaśniającą) a zależną (wyjaśnianą) zanika po wprowadzeniu trzeciej zmiennej, w postaci mediatora, co świadczy o pełnej mediacji. Negatywne treści poznawcze są dodatnio powiązane $\mathrm{z}$ zakłóceniami w kluczowych przekonaniach, a te $\mathrm{z}$ kolei wiążą się dodatnio z objawami PTSD. Wskazuje to, że im większe nasilenie negatywnych treści przejawia osoba, która doświadczyła traumy, i im większa jest jej skłonność do dokonywania ponownej analizy posiadanych przekonań, tym będzie prezentować wyższy poziom objawów PTSD. Podobne zależności występują, gdy za zmienne zależne przyjmiemy objawy PTSD w postaci intruzji (ryc. II) i pobudzenia (ryc. III).

Bardziej szczegółowe analizy, uwzględniające jako zmienną niezależną poszczególne obszary negatywnych treści poznawczych, wskazują na istotne znaczenie negatywnych przekonań dotyczących własnej osoby dla zakłóceń w kluczowych przekonaniach oraz utrzymywania się objawów PTSD, tj. wyniku ogólnego, intruzji oraz pobudzenia (ryc. IV-VI).

We wszystkich wymienionych przypadkach mamy do czynienia z pełną mediacją, gdyż po wprowadzeniu mediatora zanika zależność między zmienną niezależną a zależną. Im wyższy poziom negatywnych treści dotyczących własnej osoby, tym większa skłonność do rewizji posiadanych przekonań i tym większe nasilenie objawów PTSD, szczególnie intruzji i pobudzenia.

Przeprowadzona analiza mediacji wskazała także na znaczenie negatywnych treści poznawczych dotyczących świata dla skłonności do rewizji posiadanych przekonań i podtrzymywania objawów PTSD w postaci intruzji (ryc. VII).

\section{DYSKUSJA}

Choroba nowotworowa dziecka wiąże się z wysokim poziomem stresu. Świadczą o tym uzyskane wyniki, które wskazują, że aż 80\% badanych rodziców wykazało umiarkowany lub wysoki poziom PTSD, a jedynie niecałe $20 \%$ niski. Nieco wyższe wyniki dotyczyły intruzji niż pobudzenia i unikania. Płeć, wiek oraz czas, jaki upłynął od diagnozy choroby dziecka, nie różnicowały nasilenia objawów PTSD w badanej grupie rodziców.

Brak norm dla wyników wykorzystanych w badaniach narzędzi pomiaru, tj. Inwentarza Pourazowych Treści Poznawczych oraz Inwentarza Podstawowych Przekonań Związanych z Negatywnym Zdarzeniem Życiowym, nie pozwala na ustalenie poziomu negatywnych treści poznawczych i zakłóceń $\mathrm{w}$ posiadanych przekonaniach 
struggling with their child's cancer. The only conclusion which may be drawn is that the level does not significantly deviate from data obtained by authors of aforementioned tools.

Negative cognitions and disruption of beliefs manifesting through the propensity to revise them proved to be positively correlated with an intensification of symptoms of PTSD. Obtained results confirm the assumptions of concepts emphasising the significance of negative cognitions in development and persistence of symptoms of PTSD $[7,10,13]$ as well as results of other researchers $[22,23]$.

Moreover, negative cognitions has a positive correlation with disruption of beliefs about the world and oneself, which confirms data obtained during other studies [16].

The conducted analysis of mediation showed that disruption of beliefs as a result of an experienced event, that is a child being diagnosed with cancer, served as a mediator in the relationship between negative posttraumatic content and symptoms of PTSD. Thus, it may be concluded that people who show a higher level of such a negative cognitions in connection with a higher level of disruption of beliefs show a higher level of intensity of PTSD. Obtained results suggest that persistence of symptoms of PTSD is not the result of negative cognitions as such but rather of a propensity to revise one's beliefs.

Obtained results showing a positive correlation of disruption of beliefs, i.e. a tendency to revise them, with symptoms of PTSD, are compliant with data obtained by other researchers $[16,24-26]$, but the relationship seems to be more complex. On the one hand, experiencing a traumatic event constitutes a kind of a challenge for an individual and requires them to re-analyse their core assumptions regarding the world and self. As results of conducted research showed, that consideration of oneself and the world as a result of an experienced traumatic event seems to be increasing the level of intrusion expressed in the form of invoking thoughts, memories and images from the experienced event, as well as psycho-physiological arousal.

On the other hand, re-evaluation of cognitive schemata held by someone enables the process of integration of information about the experienced event with previously shaped cognitive schemata by giving it meaning and significance [9]. That way the trauma may be processed more efficiently, which may consequently lead to occurrence of positive posttraumatic changes. Therefore, it could be expected that a propensity to revise core beliefs should decrease the intensity of PTSD. Why such a situation does not occur? It is possible that the relationship between disruption of beliefs and symptoms of PTSD is not linear, but rather curvilinear in nature. This would mean that symptoms of PTSD are fostered by the level w badanej grupie rodziców zmagających się z chorobą nowotworową dziecka. Można jedynie stwierdzić, że poziom ten nie odbiega w znaczący sposób od danych uzyskanych przez autorów wymienionych narzędzi.

Negatywne treści poznawcze i zakłócenia w posiadanych przekonaniach, wyrażające się w skłonności do ich ponownego analizowania, okazały się dodatnio powiązane z nasileniem objawów PTSD. Uzyskane wyniki potwierdzają założenia koncepcji akcentujących znaczenie negatywnych treści poznawczych w rozwoju i podtrzymywaniu objawów $\operatorname{PTSD}[7,10,13]$, a także wyniki innych badaczy $[22,23]$.

Ponadto negatywne treści poznawcze dodatnio korelowały z zakłóceniami $\mathrm{w}$ posiadanych przekonaniach na temat świata i własnej osoby, co potwierdzają rezultaty innych badań [16].

Przeprowadzona analiza mediacji wykazała, że zakłócenia w posiadanych przekonaniach, będące wynikiem doświadczonej sytuacji, jaką była choroba nowotworowa dziecka, pełnią rolę mediatora $\mathrm{w}$ relacji między negatywnymi treściami pourazowymi a objawami PTSD. Można więc stwierdzić, że osoby, które wykazują wyższy poziom tego typu negatywnych treści poznawczych, $\mathrm{w}$ powiązaniu $\mathrm{z}$ wyższym poziomem zakłóceń $\mathrm{w}$ posiadanych przekonaniach, ujawniają wyższe nasilenie PTSD. Uzyskane wyniki sugerują, że podtrzymywanie objawów PTSD wynika nie tyle z występowania samych negatywnych treści poznawczych jako takich, ile ze skłonności do rewizji posiadanych przekonań.

Uzyskane wyniki, wskazujące na dodatnie powiązania zakłóceń w posiadanych przekonaniach, czyli tendencji do ich rewizji z objawami PTSD, są zgodne z danymi uzyskanymi przez innych badaczy [16, 24-26], ale związek ten wydaje się bardziej złożony. Z jednej strony doświadczenie zdarzenia traumatycznego stanowi pewnego rodzaju wyzwanie dla jednostki i wymaga od niej ponownego przeanalizowania kluczowych założeń wobec świata i własnej osoby. To zastanawianie się nad sobą i światem $\mathrm{w}$ wyniku doświadczonego zdarzenia traumatycznego, jak wykazały wyniki przeprowadzonych badań, zdaje się zwiększać poziom intruzji, wyrażającej się w postaci przywoływania myśli, wspomnień i obrazów doświadczonego zdarzenia, a także pobudzenia psychofizjologicznego.

$\mathrm{Z}$ drugiej jednak strony reewaluacja posiadanych schematów poznawczych umożliwia proces integrowania informacji o doświadczonym zdarzeniu z posiadanymi, ukształtowanymi wcześniej schematami poznawczymi, poprzez nadanie mu sensu i znaczenia [9]. W ten sposób sprzyja bardziej efektywnemu przetworzeniu traumy, co w konsekwencji może prowadzić do występowania pozytywnych zmian potraumatycznych. Można byłoby więc oczekiwać, że skłonność do rewizji kluczowych przekonań powinna zmniejszać nasilenie PTSD. Dlaczego taka sytuacja nie występuje? Być może jest tak, że związek między zakłóceniami w posiadanych przekonaniach a objawami PTSD nie ma charakteru prostoliniowego, a raczej krzywoliniowy. Oznaczałoby to, że objawom PTSD 
of disruption of beliefs, whereas their low and very high level would rather decrease the intensity of symptoms of PTSD. The thesis would, however, require an empirical confirmation.

The process of restoration of health manifested through a decrease of symptoms of PTSD or the appearance of positive posttraumatic changes requires time and a type of readiness to re-analyse held cognitive schemata. This also suggests that any possible occurrence of posttraumatic growth is preceded by occurrence of symptoms of PTSD which are gradually subsiding as time passes and the individual undertakes cognitive activity, and they create space for positive posttraumatic changes. This seems to be confirmed by data indicating a positive correlation between PTSD and posttraumatic growth [16, 26-29]. It would also show that disruption of core beliefs manifesting through a tendency to revise them is a sort of a common mechanism lying at the feet of both negative and positive posttraumatic changes. The thesis would, however, require a confirmation through research results.

It is also possible that a positive relationship between disruption of core beliefs and intensification of symptoms of PTSD is mediated through other forms of cognitive activity, which favour persistence of symptoms of PTSD. This could be indicated by results of studies conducted among teenagers who have experienced trauma connected with earthquakes, showing that intrusive rumination served as an intermediary between disruption of core beliefs (evaluated according to the Core Beliefs Inventory) and symptoms of PTSD [25].

The conducted research has certain limitations. It was conducted on a relatively small number of parents, whose children got cancer at various times. The evaluation of changes which occurred was based on self-description, which could somehow affect the results. The research was a cross-sectional one, which does not enable drawing conclusions about the occurrence of cause-and-effect relationships. Also, it should be mentioned that the tool used during the research, i.e. the Core Beliefs Inventory, does not measure the type of held beliefs. Therefore, it is impossible to evaluate which beliefs about the world and oneself were held by an individual prior to the experience of the traumatic event, and whether, and to what degree, the occurrence of that event changed them.

Despite presented limitations and complexity of the issue, the obtained results of that research bring new content with regard to relationships between individual's beliefs and negative outcome of trauma. It should be emphasised that this is the first Polish study considering disruption of core beliefs among people who have experienced a traumatic event. It could serve as an inspiration for further search, for which it would be reasonable to determine the significance of other forms of cognitive sprzyja umiarkowany poziom zakłóceń $\mathrm{w}$ posiadanych przekonaniach, a niski oraz bardzo wysoki ich poziom raczej zmniejszałby nasilenie symptomów PTSD. Teza ta wymagałaby jednak potwierdzenia empirycznego.

Proces powrotu do zdrowia przejawiający się zmniejszaniem objawów PTSD czy pojawieniem się pozytywnych zmian potraumatycznych wymaga czasu i pewnego rodzaju gotowości do ponownego przeanalizowania posiadanych schematów poznawczych. Sugeruje to także, że ewentualne wystąpienie potraumatycznego wzrostu jest poprzedzone występowaniem objawów PTSD, które wraz z upływem czasu i podejmowaną aktywnością poznawczą jednostki stopniowo zanikają, tworząc miejsce na pozytywne zmiany potraumatyczne. Zdają się to potwierdzać dane wskazujące na dodatnie powiązania PTSD z potraumatycznym wzrostem [16, 26-29]. Wskazywałoby to również, że zakłócenia $\mathrm{w}$ posiadanych kluczowych przekonaniach, przejawiające się w tendencji do ich rewizji, są pewnym wspólnym mechanizmem leżącym u podłoża występowania zarówno negatywnych, jak i pozytywnych zmian potraumatycznych. Teza ta wymagałaby jednak potwierdzenia w wynikach badań.

Jest też możliwe, że dodatni związek między zakłóceniami w kluczowych przekonaniach a nasileniem objawów PTSD jest mediowany przez inne formy aktywności poznawczej, które sprzyjają podtrzymywaniu objawów PTSD. Wskazywałyby na to wyniki badań przeprowadzone wśród nastolatków, którzy doświadczyli traumy związanej z trzęsieniem ziemi, wskazujące, że ruminacje o charakterze natrętnym mediowały związek między zakłóceniami w kluczowych przekonaniach (ocenianych za pomocą Core Beliefs Inventory) a objawami PTSD [25].

Przeprowadzone badania wiążą się z pewnymi ograniczeniami. Przeprowadzono je na stosunkowo niewielkiej liczbie rodziców, których dzieci chorowały na raka, i w różnym czasie. Ocena występujących zmian była wynikiem samoopisu, co mogło w pewien sposób rzutować na uzyskane rezultaty. Badania miały charakter przekrojowy, co nie pozwala na wyciąganie wniosków o występowaniu zależności przyczynowo-skutkowych. Warto także nadmienić, że wykorzystane $w$ badaniach narzędzie, jakim jest Inwentarz Podstawowych Przekonań Związanych z Negatywnym Zdarzeniem Życiowym, nie mierzy rodzaju posiadanych przekonań. Nie można więc ocenić, jakie przekonania na temat świata i własnej osoby posiadała jednostka przed doświadczeniem zdarzenia traumatycznego oraz czy i w jakim stopniu wystąpienie tego zdarzenia je zmieniło.

Pomimo przedstawionych ograniczeń i złożoności zagadnienia, uzyskane wyniki badań wnoszą nowe treści w zakresie powiązań między posiadanymi przekonaniami jednostki a negatywnymi następstwami traumy. Warto podkreślić, że są to pierwsze polskie badania uwzględniające zakłócenia w kluczowych przekonaniach u osób, które doświadczyły sytuacji traumatycznej. Mogą one stanowić inspirację do dalszych poszukiwań, w których zasadne byłoby ustalenie znaczenia także innych form 
activity resulting from the experienced traumatic event, including ruminations. Thus, it seems that the determination whether and how the tendency to revise one's core beliefs is connected with posttraumatic growth is an interesting and important issue. Also, the role of emotional processing connected with undertaken cognitive activity for the outcome of trauma should be verified. It seems that the dynamics of posttraumatic changes is another critical issue; however, it would require conducting a longitudinal study.

The presented problem may also be of significance for practical applications. Cognitive and emotional processing, which is connected with the former, serves an important role in the course of therapy among people who have experienced trauma. This is why in case of a crisis intervention, as well as in case of preventive programmes, more attention should be paid to the development of the ability to process trauma, but mainly by encouraging one to revise cognitive schemata which were distorted by trauma. The effectiveness of such a therapy conducted as a cognitive-behavioural therapy is shown by Ehlers and Clark [13], who emphasise the need to change dysfunctional cognitions to more flexible content favouring the process of recovery. Such changes are also connected with the ability to express emotions, mainly fear, and working through them, which favours posttraumatic adaptation [30].

\section{CONCLUSIONS}

The obtained results allow the following conclusions to be drawn:

- Negative cognitions and disruption of core beliefs favour the persistence of PTSD symptoms.

- Disruption of beliefs is a mediator in the relationship between negative cognitions and symptoms of PTSD.

- A change in cognitive schemata that are distorted by trauma may contribute to reducing symptoms of PTSD. aktywności poznawczej wynikającej z doświadczonego zdarzenia o charakterze traumatycznym, w tym ruminacji. Interesującym i ważnym zagadnieniem wydaje się ustalenie, czy i w jaki sposób skłonność do rewizji kluczowych przekonań wiąże się z potraumatycznym wzrostem. Warto byłoby również sprawdzić, jaką rolę dla następstw traumy pełni emocjonalne przetwarzanie, które jest powiązane $\mathrm{z}$ podejmowaną aktywnością poznawczą. Istotnym zagadnieniem wydaje się też dynamika zmian potraumatycznych, wymagałoby to jednak przeprowadzenia badań o charakterze podłużnym.

Prezentowana problematyka może mieć istotne znaczenie dla praktyki. Poznawcze, ale także powiązane z nim emocjonalne przetwarzanie odgrywa istotną rolę w przebiegu terapii u osób, które doznały traumy. Dlatego też $\mathrm{w}$ interwencji kryzysowej, ale także w programach profilaktycznych należałoby zwrócić większą uwagę na rozwijanie umiejętności przetwarzania traumy, przede wszystkim poprzez zachęcanie do rewizji - zniekształconych w wyniku doświadczonej traumy - schematów poznawczych. Na skuteczność tego typu terapii, prowadzonej w nurcie poznawczo-behawioralnym, wskazują Ehlers i Clark [13], akcentując potrzebę zmiany dysfunkcjonalnych treści poznawczych na bardziej elastyczne, sprzyjające procesowi zdrowienia. Tego typu zmiany wiążą się także z umiejętnościami ujawniania emocji, głównie lęku, i ich przepracowania, co sprzyja adaptacji potraumatycznej [30].

\section{WNIOSKI}

Uzyskane wyniki pozwalają na sformułowanie następujących wniosków:

- Negatywne treści poznawcze oraz zakłócenia w kluczowych przekonaniach sprzyjają utrzymywaniu się objawów PTSD.

- Zakłócenia w posiadanych przekonaniach pełnią rolę mediatora $\mathrm{w}$ relacji między negatywnymi treściami poznawczymi a objawami PTSD.

- Zmiana zniekształconych w wyniku doznanej traumy schematów poznawczych może przyczynić się do redukcji objawów PTSD.

Conflict of interest/Konflikt interesu

Absent./Nie występuje.

Financial support/Finansowanie

Absent./Nie występuje. 


\section{References/Piśmiennictwo}

1. Devine K, Reed-Knight B, Loiselle K, Fenton N, Blount R. Posttraumatic growth in young adults who experienced serious childhood illness: A mixed-methods approach. J Clin Psychol Med Settings 2010; 17: 340-348.

2. Cernvall M, Skogseid E, Carlbring P, Ljungman L, Lijungman G, von Essen L. Experiential avoidance and rumination in parents of children on cancer treatment: Relationships with posttraumatic stress symptoms and symptoms of depression. J Clin Psychol Med Settings 2016; 23: 67-76.

3. Kazak AE, Boeving CA, Alderfer MA, Hwang WT, Reilly A. Posttraumatic stress symptoms during treatment in parents of children with cancer. J Clin Oncol 2005; 23: 7405-7410.

4. Ljungman L, Cernvall M, Gronqvist H, Ljótsson B, Ljungman G, von Essen L. Long-term positive and negative psychological late effects for parents of childhood cancer survivors: A systematic review. PLoS One 2014; 9: 1033-1040.

5. Baran J. Zastosowanie koncepcji stresu traumatycznego w badaniach dzieci z chorobami nowotworowymi i ich rodziców. Psychoonkologia 2009; 13: 28-32.

6. Horowitz M, Wilner N, Alvarez W. Impact of Event Scale: A measure of subjective stress. Psychosom Med 1979; 41: 209-218.

7. Foa EB, Rothbaum BO. Treating the trauma of rape: Cognitive-behavioral therapy for PTSD. New York: Guilford Press; 1998.

8. Dragan M, Gulcz M, Wójtowicz S. Adaptacja Posttraumatic Cognitions Inventory (PTCI): raport ze wstępnego badania walidacyjnego Inwentarza Pourazowych Treści Poznawczych. Przegląd Psychologiczny 2005; 48: 417-430.

9. Williams R, Davis M, Millsap R. Development of the Cognitive Processing of Trauma Scale. Clin Psychol Psychother 2002; 9: 349-360.

10. Janoff-Bulman R. Shattered assumptions: Towards a new psychology of trauma. New York: The Free Press; 1992.

11. Załuski M, Gajdosz M. Skala Założeń Wobec Świata - polska adaptacja i analiza walidacyjna World Assumptive Scale. Psychoterapia 2012; 3: 17-31.

12. Lilly MM, Valdez CE, Graham-Bermann SA. The mediating effect of world assumptions on the relationships between trauma exposure and depression. J Interpers Violence 2011; 26: 2499-2516.

13. Ehlers A, Clark DM. A cognitive model of posttraumatic stress disorder. Behav Res Ther 2000; 38: 319-345.

14. Calhoun LG, Cann A, Tedeschi RG. The posttraumatic growth model: Sociocultural considerations. In: Posttraumatic growth and culturally competent practice: Lessons learned from around the globe. Weiss T, Berger R (eds.). New Jersey: John Wiley \& Sons; 2010; pp. 1-14.

15. Ogińska-Bulik N. Negatywne i pozytywne następstwa doświadczonej traumy - rola ruminacji. Psychiatria i Psychologia Kliniczna 2016; 16: 182-187.

16. Cann A, Calhoun L, Tedeschi R, Kilmer R, Gil-Rivas V, Vishnevsky T, et al. The Core Beliefs Inventory: a brief measure of disruption in the assumptive world. Anx Stress Coping 2010; 23: 19-34.

17. Weiss D, Marmar C. The Impact of Event Scale - Revised. In: Assessing psychological trauma and PTSD: A handbook for practitioners. Wilson J, Keane T (eds.). New York: Guilford Press; 1997; pp. 399-411.

18. Juczyński Z, Ogińska-Bulik N. Pomiar zaburzeń po stresie traumatycznym - polska wersja zrewidowanej Skali Wpływu Zdarzeń. Psychiatria 2009; 6: 15-25.

19. Foa EB, Ehlers A, Clark DM, Tolin DF, Orsillo SM. The Posttraumatic Cognitions Inventory (PTCI): Development and validation. Psychol Assess 1999; 11: 303-314.

20. Preacher K, Hayes AF. Asymptotic and resampling strategies for assessing and comparing indirect effects in multiple mediator models. Behav Res Ther 2008; 40: 879-891.

21. Cichocka A, Bilewicz M. Co się kryje w nieistotnych efektach statystycznych? Możliwości zastosowania analizy supresji w psychologii społecznej. Psychologia Społeczna 2010; 5: 191-198.

22. Cieslak R, Benight C, Caden Lehman V. Coping self-efficacy mediates the effects of negative cognitions on posttraumatic distress. Behav Res Ther 2008; 46: 788-798.

23. Cyniak-Cieciura M, Popiel A, Zawadzki B. General self-efficacy level and changes in negative posttraumatic cognitions and posttraumatic stress disorder (PTSD) symptoms among motor vehicle accident survivors after PTSD therapy. Psychological Studies 2015; 53: 18-29.

24. Lindstrom CM, Cann A, Calhoun LG, Tedeschi RG. The relationship of core belief challenge, rumination, disclosure, and sociocultural elements to posttraumatic growth. Psychological Trauma: Theory, Research Practice and Policy 2013; 5: 50-55.

25. Zhou X, Wu X, Fu F, An Y. Core belief challenge and rumination as predictors of PTSD and PTG among adolescent survivors of the Wenchuan earthquake. Psychol Trauma 2015; 7: 391-397.

26. Barton S, Boals A, Knowles L. Thinking about trauma: The unique contributions of event centrality and posttraumatic cognitions in predicting PTSD and posttraumatic growth. J Trauma Stress 2013; 26: 718-726.

27. Helgeson V, Reynolds K, Tomich P. A meta-analytic review of benefit finding and growth. J Consult Clin Psychol 2006; 74: 797-816.

28. Ogińska-Bulik N, Juczyński Z. Rozwój potraumatyczny - charakterystyka i pomiar. Psychiatria 2010; 7: 129-142.

29. Ogińska-Bulik N, Juczyński Z. Konsekwencje doświadczanych negatywnych wydarzeń życiowych - objawy stresu pourazowego i potraumatyczny wzrost. Psychiatria 2012; 9: 1-10.

30. Foa EB, Chrestman KR, Gilboa-Schechtman E. Przedłużona ekspozycja w terapii PTSD nastolatków. Emocjonalne przetwarzanie traumatycznych doświadczeń. Sopot: Gdańskie Wydawnictwo Psychologiczne; 2014. 